\title{
Original Research Organic Carbon Content and Its Fractions in Soils of Multi-Year Fertilization Experiments
}

\author{
Zbigniew Mazur*, Teofil Mazur \\ Chair of Environmental Chemistry, University of Warmia and Mazury in Olsztyn, \\ pl. Lodzki 4, 10-727 Olsztyn, Poland \\ Received: 23 September 2014 \\ Accepted: 1 April 2015
}

\begin{abstract}
This paper describes the influence of the annual application of natural and mineral fertilizers for a period of many years on organic carbon content and its fractions in the arable layer of soil. In experiment I, cow manure and slurry were applied to lessive soil, while experiment II involved the application of pig manure and slurry to brown soil. The influence of the applied fertilizers on the amount and quality of organic matter was assessed by determining C-org. and its fractions using $\mathrm{KMnO}_{4}$ solutions of various concentrations, as well as humic compounds extracted using $\mathrm{Na}_{4} \mathrm{P}_{2} \mathrm{O}_{7}$ and $\mathrm{NaOH}$. The average increase of organic carbon as a result of fertilization in relation to the control group was $1.94 \mathrm{~g}^{\mathrm{kg}} \mathrm{kg}^{-1}$ in lessive soil and $1.41 \mathrm{~g}^{\mathrm{kg}} \mathrm{kg}^{-1}$ in brown soil. Among the applied fertilizers, manure had the most beneficial effect on C-org. content. When compared to manure, the effect of slurry and NPK applied in doses balanced with manure using nitrogen was found to be $81.9 \%$ in lessive soil and $82.7 \%$ in brown soil, whereas in the case of mineral fertilizers it was $78.0 \%$ and $75.8 \%$ for the two soils, respectively. The effect of slurry at a dose balanced with manure using organic carbon was $87.6 \%$ and $94.2 \%$, respectively. Fertilization led to an increase in the total content of oxidized $\mathrm{KMnO}_{4}$ fractions in lessive soil from $0.29 \mathrm{~g} \cdot \mathrm{kg}^{-1}$ in the plot of land with NPK to $1.16 \mathrm{~g} \cdot \mathrm{kg}^{-1}$ in that with manure. In the case of brown soil subjected to the same kinds of fertilization, these changes were smaller, amounting to 0.09 $\mathrm{g} \cdot \mathrm{kg}^{-1}$ and $0.51 \mathrm{~g} \cdot \mathrm{kg}^{-1}$ soil, respectively. The studies also confirmed that 1.33 times more of the fraction dissolved in $\mathrm{Na}_{4} \mathrm{P}_{2} \mathrm{O}_{7}$ solution, 2.34 times more fulvic acids, 2.23 times more humic acids, and 2.18 times more of the non-hydrolyzable fraction in lessive than brown soil. The percentage share of humic acids in C-org. was highest for both types of soils when manure was applied as fertilizer.
\end{abstract}

Keywords: organic and mineral fertilization, organic carbon, soil

\section{Introduction}

Among the numerous agrotechnical procedures, the rational management of soil organic matter is of particular importance when it comes to production/ecology [1] because numerous processes that take place in the crop environment depend on its content $[2,3]$. Natural and organic fertilizers, as well as dead plant matter and micro- or mesofauna, are the basic sources of enriching soils with organic matter, which is

*e-mail: zbigniew.mazur@uwm.edu.pl the substrate from which humus is formed [4, 5]. A positive or negative humus balance and its quality features are determined by the direction of biochemical changes and the speed at which organic soil matter is mineralized [6-8]. An indicator of changes in the organic matter of soil is the total organic carbon content and its fractions, which are sensitive to changes taking place in the soil environment $[9,10]$.

In the case of farms specializing in animal production, the amounts of fertilizer produced necessitate their annual application to crops. The effects of such fertilization ought to be assessed by the results of multi-year field experiments [11]. 
Table 1. Doses of fertilizer components applied in the experiments.

\begin{tabular}{|c|c|c|c|c|c|c|c|c|}
\hline \multirow{3}{*}{ Fertilizers } & \multicolumn{4}{|c|}{$\begin{array}{l}\text { Experiment I with the application } \\
\text { of cow manure and slurry. } \\
\text { Average for years 1972-2008 }\end{array}$} & \multicolumn{4}{|c|}{$\begin{array}{l}\text { Experiment II with the application } \\
\text { of pig manure and slurry. } \\
\text { Average for years 1973-2009 }\end{array}$} \\
\hline & \multirow{2}{*}{$\begin{array}{c}\text { Organic fertilizers } \\
\text { t.ha' }{ }^{-1} \text { f.m. }\end{array}$} & \multicolumn{3}{|c|}{ Mineral fertilizers $\mathrm{kg} \cdot \mathrm{ha}^{-1}$} & \multirow{2}{*}{$\begin{array}{c}\text { Organic fertilizers } \\
\mathrm{t} \cdot \mathrm{ha}^{-1} \mathrm{f} . \mathrm{m} .\end{array}$} & \multicolumn{3}{|c|}{ Mineral fertilizers $\mathrm{kg} \cdot \mathrm{ha}^{-1}$} \\
\hline & & $\mathrm{N}$ & $\mathrm{P}$ & $\mathrm{K}$ & & $\mathrm{N}$ & $\mathrm{P}$ & K \\
\hline Manure & 22.8 & - & - & - & 21.9 & - & - & - \\
\hline Slurry dose I (dI) & 40.0 & - & - & - & 43.1 & - & - & - \\
\hline Surry dose II (dII) & 76.0 & - & - & - & 118.1 & - & - & - \\
\hline NPK & - & 110 & 38 & 108 & - & 131 & 43 & 116 \\
\hline
\end{tabular}

Table 2. Chemical composition of organic fertilizers (\% FM).

\begin{tabular}{|l|c|c|c|c|}
\hline \multirow{2}{*}{ Nutrient } & \multicolumn{2}{|c|}{$\begin{array}{c}\text { Experiment I } \\
\text { Average for years } \\
1972-2008\end{array}$} & \multicolumn{2}{c|}{$\begin{array}{c}\text { Experiment II } \\
\text { Average for years } \\
1973-2009\end{array}$} \\
\cline { 2 - 5 } & $\begin{array}{c}\text { Cow } \\
\text { manure }\end{array}$ & $\begin{array}{c}\text { Cow } \\
\text { slurry }\end{array}$ & $\begin{array}{c}\text { Pig } \\
\text { manure }\end{array}$ & $\begin{array}{c}\text { Pig } \\
\text { slurry }\end{array}$ \\
\hline Dry matter & 23.90 & 8.43 & 27.21 & 5.42 \\
\hline Organic Carbon & 8.96 & 3.01 & 9.14 & 1.70 \\
\hline Nitrogen & 0.49 & 0.27 & 0.59 & 0.30 \\
\hline Phosphorus & 0.15 & 0.11 & 0.28 & 0.19 \\
\hline Potassium & 0.41 & 0.33 & 0.54 & 0.21 \\
\hline Magnesium & 0.09 & 0.05 & 0.12 & 0.05 \\
\hline
\end{tabular}

The present work describes the influence of fertilization by manure, slurry, and mineral fertilizers (NPK) on organic carbon content, and the quality of humic compounds in lessive and brown soil.

\section{Materials and Methods}

Soil samples taken from the $0.25 \mathrm{~cm}$ layer of soil of two field experiments conducted in 2008 and 2009 in randomized complete block design in 6 replications were used in the study. Experiment I was set up in 1972 in Balcyny $\left(53^{\circ} 35^{\prime} 45^{\prime \prime} \mathrm{N}, 1^{\circ} 51^{\prime} 06^{\prime \prime} \mathrm{E}\right)$ on lessive soil of a rye complex of IVa soil valuation class, with the application cow manure and slurry. Sandy clay containing 5-7\% silt and clay fractions was present in the arable layer of the soil. Experiment II was set up in 1973 in Tomaszkowo (53 $35^{\prime} 45^{\prime \prime} \mathrm{N}$, $\left.19^{\circ} 51^{\prime} 06^{\prime \prime} \mathrm{E}\right)$ on brown soil of a rye complex (IVb soil valuation class), with the application of pig manure and slurry. The arable layer of this soil was made up of slightly loamy sand with $2-2.5 \%$ silt and clay fractions.

Crops in the experiment were cultivated in the following rotation: potato, spring barley+red clover and grass companion crop, red clover with grasses, winter rapeseed, winter wheat+winter rye aftercrop, corn for silage, spring barley, winter wheat. Clover with grasses was grown only in the first two cycles of the crop rotation in experiment I, and only in the first cycle in experiment II. The doses of slurry and manure were calculated each year, directly prior to their application to soil, based on dry matter, organic carbon, and nitrogen contents. All agrotechnical procedures were conducted at optimal times. Natural and mineral fertilizers were applied prior to the sowing or planting of crops. Slurry in the first dose (dI), manure, and mineral fertilizers were applied in doses balanced with nitrogen. Dose II of slurry (dII) was established in such a way that the amount of organic carbon introduced along with it would be equal to that of the applied manure dose.

Table 1 presents the annual average doses of natural and mineral fertilizers, whereas Table 2 shows the average chemical composition of natural fertilizers. The content of C-org. was established using a CNS element analyzer produced by Coestech. Three fractions of organic matter susceptible to oxidation with potassium permanganate $(\mathrm{V})$ at increasing concentrations (i.e. $0.033,0.167$, and $0.333 \mathrm{M}$ ) were determined with the method devised by Loginova et al. [12]. The content of humic compounds was assessed using the Boratyński and Wilk's method [13]. After extracting bitumen compounds using a mixture of alcohol and benzene (1:1), humic compounds were extracted with $0.025 \mathrm{M} \mathrm{Na}_{4} \mathrm{P}_{2} \mathrm{O}_{7}$, whereas $0.1 \mathrm{M} \mathrm{NaOH}$ was used to extract humic and fulvic acids. Humic acids were separated from the obtained solution using $0.25 \mathrm{M} \mathrm{H}_{2} \mathrm{SO}_{4}$, with fulvic acids constituting the remainder.

The results of each experiment were subjected to statistical analysis using Tukey's analysis of variance. The experiments were compared with the t-test for independent variables, assessing differences between the average results; for this purpose, the Statistica 9 program was used.

\section{Results and Discussion}

The content of organic carbon in the soils of two multiyear fertilization experiments has been presented numerically in Table 3 . The data in Table 3 indicate that the average C-org. content in lessive soil was 1.90 times higher than in brown soil. From the applied fertilizers, manure was 
Table 3. Content of organic carbon and fractions oxidized with $\mathrm{KMnO}_{4}$ solution, $\mathrm{g}$ C-org $\cdot \mathrm{kg}^{-1}$ soil.

\begin{tabular}{|c|c|c|c|c|c|c|}
\hline \multirow{2}{*}{ Fertilization } & \multirow{2}{*}{ Organic $\mathrm{C}$} & \multicolumn{5}{|c|}{ Organic $\mathrm{C}$ fractions } \\
\hline & & I & II & III & $\mathrm{I}+\mathrm{II}+\mathrm{III}$ & IV \\
\hline \multicolumn{7}{|c|}{ Lessive soil } \\
\hline I No fertilization & 8.58 & 0.59 & 0.23 & 0.22 & 1.04 & 7.54 \\
\hline II Slurry dI & 9.92 & 0.81 & 0.26 & 0.54 & 1.61 & 8.31 \\
\hline III Slurry dII & 10.61 & 0.82 & 0.34 & 0.91 & 2.07 & 8.54 \\
\hline IV Manure & 12.11 & 1.13 & 0.61 & 0.46 & 2.20 & 9.91 \\
\hline V NPK & 9.44 & 0.76 & 0.35 & 0.22 & 1.33 & 8.11 \\
\hline Average & $10.13^{\mathrm{a}}$ & $0.82^{\mathrm{b}}$ & $0.36^{\mathrm{c}}$ & $0.47^{\mathrm{d}}$ & $1.64^{\mathrm{e}}$ & $8.48^{\mathrm{f}}$ \\
\hline $\mathrm{LSD}_{0.05}$ & 0.94 & 0.05 & 0.03 & 0.04 & 0.12 & 0.56 \\
\hline \multicolumn{7}{|c|}{ Brown soil } \\
\hline I No fertilization & 4.21 & 0.35 & 0.11 & 0.39 & 0.85 & 3.36 \\
\hline II Slurry dI & 5.27 & 0.45 & 0.18 & 0.50 & 1.13 & 4.14 \\
\hline III Slurry dII & 6.00 & 0.46 & 0.20 & 0.54 & 1.20 & 4.80 \\
\hline IV Manure & 6.37 & 0.46 & 0.22 & 0.68 & 1.36 & 5.01 \\
\hline V NPK & 4.83 & 0.40 & 0.19 & 0.35 & 0.94 & 3.89 \\
\hline Average & $5.34^{\mathrm{a}}$ & $0.42^{\mathrm{b}}$ & $0.18^{\mathrm{c}}$ & $0.49^{\mathrm{d}}$ & $1.10^{\mathrm{e}}$ & $4.24^{\mathrm{f}}$ \\
\hline $\mathrm{LSD}_{0.05}$ & 0.43 & 0.03 & 0.01 & 0.03 & 0.08 & 0.27 \\
\hline
\end{tabular}

a-a, b-b, c-c, e-e, f-f - insignificant differences at $\mathrm{p}<0.05{ }^{\mathrm{d}-\mathrm{d}}-$ significant differences at $\mathrm{p}<0.05$

found to have the most positive influence on the accumulation of this element in soils. In comparison to manure, which was accepted as $100 \%$, the effect of slurry dI was $81.92 \%$ and $82.73 \%$, slurry dII balanced with manure using organic carbon at $87.61 \%$ and $94.19 \%$, and mineral fertilizers $77.95 \%$ and $75.82 \%$ in lessive and brown soils, respectively. The relative increase of C-org. content has been presented in Fig. 1. In lessive soil the average increase of C-org. content was $22.61 \%$ when compared to the control group, with the increase in brown soil amounting to $33.49 \%$. A more advantageous effect of applying manure,

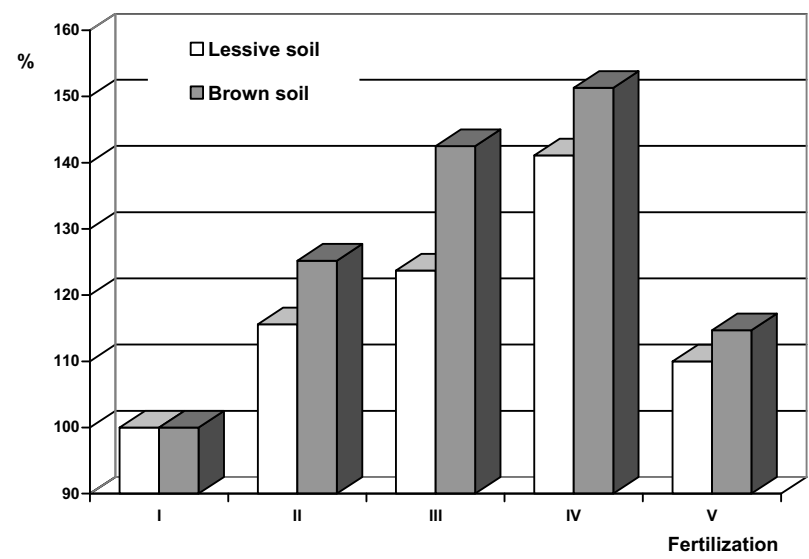

Fig. 1. Influence of multi-year fertilization on relative increases in organic carbon content. slurry, and other organic fertilizers on storing organic carbon in soils over their mineral counterparts was revealed by Capriel [14] as well as Sosulski et al. [15, 16], whereas Wang et al. [17] and Li et al. [18] proved that the long-term application of manure leads to a significant increase in the organic carbon content of soil.

The results of determining the content of three fractions of organic matter oxidized with potassium permanganate (V) solutions, as well as fraction IV (non-oxidized carbon) have been presented in Table 3. The content of fractions oxidized with $\mathrm{KMnO}_{4}$ solution is a good indicator of the presence of active humus [19, 20]. The applied fertilization caused the sum of oxidized fractions $(\mathrm{I}+\mathrm{II}+\mathrm{III})$ in lessive soil to increase, from $0.29 \mathrm{~g} \cdot \mathrm{kg}^{-1}$ in the NPK group to 1.16 $\mathrm{g} \cdot \mathrm{kg}^{-1}$ soil for manure. In the case of brown soil, the changes were smaller, i.e. $0.09 \mathrm{~g} \cdot \mathrm{kg}^{-1}$ and $0.51 \mathrm{~g} \cdot \mathrm{kg}^{-1}$ soil, respectively. The increase in the content of non-oxidized carbon (fraction IV) ranged from $0.57-2.37 \mathrm{~g} \cdot \mathrm{kg}^{-1}$ in lessive soil, and $0.53-1.65 \mathrm{~g} \cdot \mathrm{kg}^{-1}$ in brown soil. The percentage share of individual fractions is important when assessing the ecological quality of humic compounds (Table 4). The sum of three fractions susceptible to oxidation averaged $16.02 \%$ in lessive soil and $20.49 \%$ in brown soil of total C-org. content. Slurry in the dose balanced with manure using organic carbon had the most positive effect on the sum of oxidized fractions in lessive soil, whereas the same fertilizer applied in dose II and balanced with manure using organic carbon proved to be most effective in brown soil. The dom- 
Table 4. Percentage share of fractions oxidized with $\mathrm{KMnO}_{4}$ solution in total C-org. content.

\begin{tabular}{|c|c|c|c|c|c|}
\hline Fertilization & Fr I & Fr II & Fr III & Fr I+Fr II+Fr III & Fr IV \\
\hline \multicolumn{6}{|c|}{ Lessive soil } \\
\hline I No fertilization & 6.88 & 2.68 & 2.56 & 12.12 & 87.88 \\
\hline II Slurry dI & 8.17 & 2.62 & 5.44 & 16.23 & 83.77 \\
\hline III Slurry dII & 7.73 & 3.20 & 8.58 & 19.51 & 80.49 \\
\hline IV Manure & 9.33 & 5.04 & 3.80 & 18.17 & 81.83 \\
\hline V NPK & 8.05 & 3.71 & 2.33 & 14.09 & 85.91 \\
\hline Average & 8.03 & 3.45 & 4.54 & 16.02 & 83.98 \\
\hline \multicolumn{6}{|c|}{ Brown soil } \\
\hline I No fertilization & 8.31 & 2.61 & 9.26 & 20.19 & 79.81 \\
\hline II Slurry dI & 8.53 & 3.42 & 9.49 & 21.44 & 78.56 \\
\hline III Slurry dII & 7.67 & 3.33 & 9.00 & 20.00 & 80.00 \\
\hline IV Manure & 7.22 & 3.45 & 10.68 & 21.35 & 78.65 \\
\hline V NPK & 8.28 & 3.93 & 7.25 & 19.46 & 80.54 \\
\hline Average & 8.00 & 3.35 & 9.14 & 20.49 & 79.51 \\
\hline
\end{tabular}

inant fraction in lessive soil was fraction I (the most susceptible to oxidation), whereas fraction III, which is oxidized by the highest concentration of $\mathrm{KMnO}_{4}$ solution, dominated in brown soil. Fraction IV, which does not undergo oxidation, accounted for an average of $83.98 \%$ and $79.51 \%$ total C-org. content in lessive and brown soil, respectively. For farmland fertilized with manure and slurry, the percentage share of this fraction was smaller than when NPK fertilization was applied in both kinds of soil. The superiority of organic over mineral fertilization in terms of organic carbon content susceptible to oxidation with $\mathrm{KMnO}_{4}$ in arable land was confirmed by the results of studies by Verma et al. [21] and Sequeira [22]. When researching Australian soils, Blair et al. [23] and Blair [24] concluded that the percentage share of the fraction susceptible to oxidation with $0.333 \mathrm{M}$ potassium permanganate depends on the species of cultivated plants and the amount of post-harvest remains left behind. According to Tobiašová [25], the amount of oxidized carbon depends on the water content of the soil, and the ratio of $\mathrm{C}: \mathrm{N}$, which is connected with the transformation processes of organic matter in soil.

The content of humus compound fractions in soils is presented in Table 5. In lessive soil, 1.33 times more of the fraction dissolved in a solution of $\mathrm{Na}_{4} \mathrm{P}_{2} \mathrm{O}_{7}, 2.34$ times more fulvic acids, 2.23 times more humic acids, and 2.18 times more of the non-hydrolyzable fraction were confirmed than in brown soil. Fulvic and humic acid content in lessive soil was most influenced by manure, whereas slurry applied at a dose balanced with manure, and NPK with nitrogen (dI) were least effective. Brown soil exhibited the highest content of fulvic acids in the land plot to which slurry was applied at a dose balanced with manure using organic car- bon (dII). The worst C-HA/C-FA ratios were noted in both soil types fertilized with dI of slurry balanced with manure using nitrogen [26]. According to Lapa et al. [27], soil liming and fertilization with manure positively affected the content of humic and fulvic acids as well as their ratio. Table 6 presents the percentage share of bitumen and humic compounds. In brown soil, the average share of the fraction soluble in sodium pyrophosphate was 1.42 times higher than in lessive soil. The share of C-FH and C-HA, as well as bitumen fractions, were similar in both kinds of soil, whereas $\mathrm{C}-\mathrm{NH}$ content was 1.15 times higher in lessive than brown soil.

According to Guimaraes et al. [28], the content of humic compounds in soils depends on how the land is utilized, the species of cultivated plants, and the management of post-harvest remains. Cieścińska and Dębska [29] write that the content of C-HA and C-FA in soil depends on the types of fertilization and system of crop rotations. The highest C-HA to C-FA ratio was noted in soils that had undergone organic-mineral fertilization for many years. Gong et al. [30] revealed the highest increase in C-HA and C-FA content to be in soil fertilized with manure for 18 years. Pospíśilová et al. [31] and Dębska et al. [32] stated that the content of organic carbon and its labile forms, as well as humic and fulvic acids, is dependent on soil type, management methods, and agricultural practices.

\section{Conclusions}

The results of experiments in which manure, slurry, and mineral fertilizers were applied for a period of 36 years show that an increase in organic carbon content depends on the 
Table 5. Content of organic carbon and fraction of soil humic compounds, $\mathrm{g}$ C-org $\cdot \mathrm{kg}^{-1}$.

\begin{tabular}{|c|c|c|c|c|c|c|c|}
\hline Fertilization & Organic C & $\mathrm{C}_{\mathrm{BIT}}$ & $\mathrm{C}_{\mathrm{SP}}$ & $\mathrm{C}_{\mathrm{FA}}$ & $\mathrm{C}_{\mathrm{HA}}$ & $\mathrm{C}_{\mathrm{NH}}$ & $\mathrm{C}_{\mathrm{HA}}: \mathrm{C}_{\mathrm{FA}}$ \\
\hline \multicolumn{8}{|c|}{ Lessive soil } \\
\hline I No fertilization & 8.58 & 1.04 & 1.82 & 0.70 & 0.87 & 4.15 & 1.24 \\
\hline II Slurry dI & 9.92 & 1.15 & 2.11 & 0.99 & 1.02 & 4.65 & 1.03 \\
\hline III Slurry dII & 10.61 & 1.27 & 2.25 & 0.99 & 1.17 & 4.93 & 1.18 \\
\hline IV Manure & 12.11 & 1.43 & 2.25 & 1.42 & 1.60 & 5.41 & 1.13 \\
\hline V NPK & 9.44 & 1.04 & 2.08 & 1.06 & 1.12 & 4.14 & 1.06 \\
\hline Average & $10.14^{\mathrm{a}}$ & $1.19^{\mathrm{b}}$ & $2.10^{\mathrm{c}}$ & $1.03^{\mathrm{d}}$ & $1.16^{\mathrm{e}}$ & $4.66^{\mathrm{f}}$ & $1.13^{\mathrm{g}}$ \\
\hline $\mathrm{LSD}_{0.05}$ & 0.82 & 0.09 & 0.14 & 0.08 & 0.07 & 0.36 & 0.08 \\
\hline \multicolumn{8}{|c|}{ Brown soil } \\
\hline I No fertilization & 4.21 & 0.53 & 1.16 & 0.33 & 0.44 & 1.75 & 1.33 \\
\hline II Slurry dI & 5.27 & 0.65 & 1.50 & 0.52 & 0.48 & 2.12 & 0.93 \\
\hline III Slurry dII & 6.00 & 0.66 & 1.90 & 0.48 & 0.54 & 2.42 & 1.13 \\
\hline IV Manure & 6.37 & 0.78 & 1.90 & 0.45 & 0.68 & 2.56 & 1.51 \\
\hline V NPK & 4.83 & 0.67 & 1.46 & 0.42 & 0.46 & 1.82 & 1.10 \\
\hline Average & $5.34^{\mathrm{a}}$ & $0.66^{\mathrm{b}}$ & $1.58^{\mathrm{c}}$ & $0.44^{\mathrm{d}}$ & $0.52^{\mathrm{e}}$ & $2.13^{\mathrm{f}}$ & $1.20^{\mathrm{g}}$ \\
\hline $\mathrm{LSD}_{0.05}$ & 0.43 & 0.05 & 0.10 & 0.03 & 0.03 & 0.16 & 0.08 \\
\hline
\end{tabular}

$\mathrm{C}_{\mathrm{BIT}}$ - bitumen carbon, $\mathrm{C}_{\mathrm{PF}}-$ carbon soluble in sodium pyrophosphate, $\mathrm{C}_{\mathrm{HA}}$ - carbon of humic acids, $\mathrm{C}_{\mathrm{FA}}$ - carbon of fulvic acids, $\mathrm{C}_{\mathrm{HA}}: \mathrm{C}_{\mathrm{FA}}-$ ratio of carbon of humic acids to carbon of fulvic acids, $\mathrm{C}_{\mathrm{NH}}-$ nonhydrolyzable carbon

a-a, b-b, c-c, d-d, e-e, f-f - insignificant differences at $\mathrm{p}<0.05$, ${ }^{\mathrm{g}-\mathrm{g}}-$ significant differences at $\mathrm{p}<0.05$

Table 6. Percentage share of bitumen and humic compounds in total C-org. content.

\begin{tabular}{|c|c|c|c|c|c|}
\hline Fertilization & $\mathrm{C}_{\mathrm{BIT}}$ & $\mathrm{C}_{\mathrm{SP}}$ & $\mathrm{C}_{\mathrm{FA}}$ & $\mathrm{C}_{\mathrm{HA}}$ & $\mathrm{C}_{\mathrm{NH}}$ \\
\hline \multicolumn{6}{|c|}{ Lessive soil } \\
\hline I No fertilization & 12.12 & 21.21 & 8.16 & 10.14 & 48.37 \\
\hline II Slurry dI & 11.59 & 21.27 & 9.98 & 10.28 & 46.88 \\
\hline III Slurry dII & 11.97 & 21.21 & 9.33 & 11.03 & 46.46 \\
\hline IV Manure & 11.81 & 18.58 & 11.73 & 13.21 & 44.67 \\
\hline V NPK & 11.02 & 22.03 & 11.23 & 11.86 & 43.86 \\
\hline Average & 11.70 & 20.86 & 10.09 & 11.30 & 46.05 \\
\hline \multicolumn{6}{|c|}{ Brown soil } \\
\hline I No fertilization & 12.59 & 27.55 & 7.84 & 10.45 & 41.57 \\
\hline II Slurry dI & 12.33 & 28.46 & 9.87 & 9.11 & 40.23 \\
\hline III Slurry dII & 11.00 & 31.67 & 8.00 & 9.00 & 40.33 \\
\hline IV Manure & 12.24 & 29.83 & 7.06 & 10.68 & 40.19 \\
\hline V NPK & 13.87 & 30.23 & 8.70 & 9.52 & 37.68 \\
\hline Average & 12.41 & 29.55 & 8.29 & 9.75 & 40.00 \\
\hline
\end{tabular}


kind of soil as well as the type of fertilizer applied. In lessive soil, with a higher C-org. content its average relative increase was smaller than in brown soil containing less of this element. Its content in soils was most effectively increased with manure; mineral fertilization and slurry, especially when applied at a dose balanced with manure using nitrogen, were found to be less effective. The applied fertilization had a positive effect on increasing the sum of organic carbon fractions oxidized with potassium permanganate $(\mathrm{V})$ and non-oxidized carbon, with the most noticeable increase noted in soil fertilized with manure, and lowest in that fertilized with NPK. More noticeable changes in the content of these fractions were observed in lessive soil than brown soil. In all of the fertilized objects, an increase in fulvic and humic acids was noted, as well as organic carbon soluble in sodium pyrophosphate and non-hydrolyzable organic carbon. The ratio of humic acids in C-org. was highest in both kinds of soil when manure fertilization was applied.

\section{References}

1. VAN EERD L.L., CONGREVES K.A., HAYES A., VERHALLEN A., HOOKER D.C. Long-term tillage and crop rotation effects on soil quality, organic carbon, and total nitrogen. Can. J. Soil Sci. 94, (3), 2014.

2. LIU X., HERBERT S.J., HASHEMI A.M., ZHANG X., DING G. Effects of agricultural management on soil organic matter and carbon transformation - a review. Plant Soil Environ. 52, (12), 531, 2006.

3. RILEY H., BAKKEGARD M. Declines of soil organic matter content under arable cropping in southeast Norway. Acta Agric. Scan., Section B-Soil Plant Sci. 56, 217, 2006.

4. MANZONI S., TROFYMOW J.A., JACKSON R.B., PORPORATO A. Stoichiometric controls dynamics on carbon, nitrogen, and phosphorus in decomposing litter. Ecol. Monogr. 80, 89, 2010.

5. KOSOBUCKI P., BUSZEWSKI B. Carbon changes in Environment, from total organic carbon to soil organic matter. Pol. J. Environ. Stud. 20, (1), 9, 2011.

6. CVETKOV M., ŠANTAVEC I., KOCJANAČKO D., TAJNŠEK A. Soil organic matter content according to different management system within long-term experiment Acta Agric. Slovenica, 95, (1), 79, 2010.

7. BAKER J.M., OCHSNER T.E., VENTEREA R.T., GRIFFIS T.J. Tillage and soil carbon sequestration - What do we really know? Agric. Ecosyst. Environ., 118, 1, 2007.

8. CHATTERJEE A. On farm assessment of tillage impact on soil carbon and associated soil quality parameters. Soil Till. Res. 104, (2), 270, 2009.

9. KOLÁŘ L., KUŽEL S., HORÁČEK J., ČECHOVÁ V., BOROVÁ-BATT J., PETERKA J. Labile fractions of soil organic matter, their quantity and quality. Plant Soil Environ. 55, (6), 245, 2009

10. HAYNES R.J. Labile Organic Matter Fractions as Central Components of the Quality of Agricultural Soils: An Overview. Adv. Agron. 85, 221, 2005.

11. MAZUR T. Influence of long-term animal slurry, manure and NPK application on organic carbon content in soils. Zesz. Probl. Post. Nauk. Rol. 411, 23, 1993 [In Polish].

12. LOGINOW W., WISNIEWSKI W., GONET S.S., CIESCINSKA B. Fractionation of organic carbon based on susceptibility to oxidation. Polish J. Soil Sci. 20, 47, 1987.
13. BORATYNSKI K., WILK K. A new method for the fractional analysis of humus in soils. Zesz. Probl. Post. Nauk Rol. 40a, 157, 1963 [In Polish].

14. CAPRIEL P. Trends in organic carbon and nitrogen contents in agricultural soils in Bavaria (south Germany) between 1986 and 2007 Europ. J. Soil. 64, 445, 2013.

15. SOSULSKI T., SZARA E., STĘPIEŃ W. Dissolved organic carbon in Luvisol under different fertilization and crop rotation. Soil Sci. Annual. 64, (3), 114, 2013.

16. SOSULSKI T., KORC M. Effects of Different Mineral and Organic Fertilization on the Content of Nitrogen and Carbon in Soil Organic Matter Fractions. Ecol. Chem. Eng. A. 18, (4), 601, 2011.

17. WANG J., LIN X., YIN R., CHU H., CHEN M., DAI J., QIN S. Changes in soil humic acid, microbial biomass carbon and invertase activity in response to fertilization regimes in a long-term field experiment. Plant Nutr. Fertil. Sci. 15, (2), 352, 2009

18. LI Z.P., LIU M., WU X.C., HAN F.X., ZHANG T.L. Effects of long-term chemical fertilization and organic amendments on dynamics of soil organic $\mathrm{C}$ and total $\mathrm{N}$ in paddy soil derived from barren land in subtropical China. Soil Till Res. 106, 268, 2010.

19. LEFROY R.D.B., BLAIR G.J., STRONG W.M. Changes in soil organic matter with cropping as measured by organic carbon fractions and ${ }^{13} \mathrm{C}$ natural isotope abundance. Plant Nutrition. 54, 551, 1993.

20. WEIL R.R., ISLAM K.R., STINE M.A., GRUVER J.B., SAMSON-LIEBIG S.E. Estimating active carbon for soil quality assessment: A simplified method for laboratory and field use. Americ. J. Alter. Agric. 18, (1), 3, 2003.

21. VERMA B.C., DATTA S.P., RATTAN R.K., SINGH A.K. Labile and stabilized fractions of soil organic carbon in some intensively cultivated alluvial soil. J Environ. Biol. 34, 1069, 2013.

22. SEQUEIRA C.H., ALLEY M.M. Soil organic matter fractions as indices of soil quality changes. Soil Sci. Soc. Americ. J. 75, 1766, 2011.

23. BLAIR G.J., LEFROY R.D.B., LISLE L. Soil carbon fractions based on their degree of oxidation and the development of a carbon management index for agricultural systems. Aust. J. Agric. Res., 46, 1459, 1995.

24. BLAIR N. Impact of cultivation and sugar-cane green trash management on carbon fractions and aggregate stability for a Chromic Luvisol in Queensland, Australia. Soil Till. Res. 55, (3-4), 2000.

25. TOBIAŠOVÁ E. Quantity and quality of soil organic matter in ecological and integrated farming system. J. Centr. Europ. Agric. 13, (3), 519, 2012.

26. GALANTINI J., ROSELL R. Long-term fertilization effects on soil organic matter quality and dynamics under different production systems in semiarid Pampean soils. Soil Till. Res. 87, 72, 2006.

27. LAPA V.V., SERAYA T.M., BOGATYREVA E.N., BIRYUKOVA O.M. The effect of long-term fertilizer application on the group and fractional composition of humus in a soddy-podzolic light loamy soil. Euras. Soil Sci. 44, (1), 100, 2011.

28. GUIMARAES D.V. SILVA GONZAGA M.I., DA SILVA T.O., DA SILVA T.L., DA SILVA DIAS N., SILVA MATIAS M.I. Soil organic matter pools and carbon fractions in soil under different land uses. Soil Till. Res. 126, 177, 2013.

29. CIEŚCIŃSKA B., DĘBSKA B. Influence of long-term fertilization and crop rotation on the quantity and quality prop- 
erties of soil humus substances. Humic Subst. Ecosyst. 8, 17, 2009.

30. GONG W., YAN X.Y. WANG J.Y., HU T.X., GONG Y.B. Effects of long-term fertilization on soil humus carbon and nitrogen fractions in a wheat-maize cropping system. Plant Nutr. Fertil. Sci. 15, (6), 1245, 2009.
31. POSPÍŠILOVÁ L., FASUROVÁ N., PETRÁŠOVÁ V. Humus content and quality under different soil tillage systems. Soil Water Res., 5, (3), 2010.

32. DĘBSKA B., SZOMBATHOVA N., BANACH-SZOTT M. Properties of humic acids of soil under different management regimes. Polish J. Soil Sci. 42, (2), 131, 2009. 
